\title{
ЗМІНИ ЛІПІДНОГО ПРОФІЛЮ У ТВАРИН 3 МОДЕЛЬОВАНИМ МЕТАБОЛІЧНИМ СИНДРОМОМ
}

Вступ. Формування атерогенних змін ліпідного профрілю при метаболічному синдромі зумовлене дією багатьох фракторів ризику. Атерогенна дисліпопротеїнемія являє собою не лише фрактор ризику розвитку та прогресування атеросклерозу, а й одну з основних складових метаболічного синдрому.

мета дослідження - оцінити зміни ліпідного профрілю у щурів із змодельованим метаболічним синдромом.

Методи дослідження. Дослідження проведено на 40 білих щурах-самцях лінії Вістар масою 200-250 ح. До контрольної групи ввійшли 8 тварин. щурів-самців основної групи (n=32) годували дієтою з високим вмістом жиру (понад 60 \% енергії від жирів) упродовж 16 тижнів, таким чином моделюючи в них розвиток метаболічного синдрому. Тварин виводили з експерименту иляхом декапітації. Ліпідний профріль у сироватці крові щурів оцінювали за допомогою біохімічного аналізатора "HTI BioChem SA" (США) і стандартних тест-наборів.

Результати й обговорення. Було встановлено, що на тлі перебігу метаболічного синдрому в щурів основної групи, порівняно з контрольною, розвивались явища гіперхолестеринемії, які характеризувалися підвищенням у крові тварин показників: загального холестеролу - на 18,38 \%, триацилгліцеролів - на 77,35 \%, ліпопротеїнів низької щільності - на 156,52 \% з одночасним зниженням рівня ліпопротеїнів високої щільності на $36,14 \%$.

Висновок. У тварин із метаболічним синдромом зміни ліпідного обміну характеризувалися гіпер- та дисліпідемією (за статистично значимо вищими рівнями загального холестеролу, триацилгліцеролів, ліпопротеїнів низької щільності на тлі зниження вмісту ліпопротеїнів високої щільності) порівняно з контрольною групою.

КЛЮЧОВІ СЛОВА: ліпопротеїни; триацилгліцероли; ліпідограма; метаболічний синдром.

ВСТУП. Розповсюдженість метаболічного синдрому (МС), який включає в себе кластер серцево-судинних сракторів ризику, пов'язаних 3 ожирінням та резистентністю до інсуліну, останнім часом різко зросла і набула характеру епідемії в багатьох розвинутих країнах [1]. Ця патологія характеризується такими метаболічними порушеннями, як гіпертригліцеридемія, зниження вмісту ліпопротеїнів високої щільності (ЛПВЩ), підвищення рівня ліпопротеїнів низької щільності (ЛПНЩ), інсулінорезистентність, аномальна толерантність до глюкози й артеріальна гіпертензія, які в поєднанні з генетичною схильністю та абдомінальним ожирінням $€$ факторами ризику розвитку цукрового діабету 2 типу, судинного запалення, атеросклерозу і захворювань нирок, печінки та серця [2].

За сучасними уявленнями, МС характеризується сукупністю порушень системної, в тому

(c) І. Я. Дзюбановський, А. М. Продан, С. Р. Підручна, Н. А. Мельник, Т. Я. Ярошенко, 2021. числі гормональної, регуляції ліпідного, вуглеводного, білкового та інших видів обміну речовин за умов дії зовнішніх і внутрішніх фракторів [3]. Відокремлення МС має значуще клінічне значення, оскільки, з одного боку, даний стан $€$ зворотним, а з іншого - потрібно вирішувати питання про тактику ведення таких хворих у зв'язку з тим, що серед осіб із МС ризик розвитку ішемічної хвороби серця чи інсульту у 3 рази вищий, при цьому значно зростає смертність від серцево-судинних захворювань [4].

Формування атерогенних змін ліпідного профрілю при МС зумовлене дією багатьох фракторів ризику [5]. Атерогенна дисліпопротеїнемія являє собою не лише фрактор ризику розвитку та прогресування атеросклерозу, а й одну з основних складових МС. Саме через це в комплексі заходів, спрямованих на максимальне зниження ризику розвитку серцево-судинних захворювань та їх ускладнень у пацієнтів із МС, корекція дисліпопротеїдемії відіграє головну роль [6]. Най- 
частішим варіантом атерогенної дисліпопротеїнемії при МС є ліпідна тріада: підвищення рівня триацилгліцеролів (ТГ) та ЛПНЩ на тлі зниження вмісту лПВЩ у сироватці крові [7]. Для скринінгу дисліпопротеїнемії застосовують різні співвідношення ліпідограми - індекси атерогенності, що $є$ незалежними предикторами серцево-судинних захворювань та дозволяють стежити за ефективністю методів терапії гіперхолестеринемії [8]. Зважаючи на особливості атерогенної дисліпопротеїнемії за умов МС, пошук ранніх предикторів метаболічних порушень, асоційованих з ними хвороб та корекція порушень обміну холестеролу (XC) мають важливе медико-соціальне значення.

Однак, незважаючи на велику кількість експериментальних та клінічних досліджень, спрямованих на з'ясування клітинних і гуморальних механізмів фрормування ускладнень (атеросклерозу, інсулінорезистентності, артеріальної гіпертензії та ін.), пов'язаних із МС, ключових моментів, що визначають черговість виникнення змін у ліпідному обміні й взаємозв'язок між цими патологічними процесами, до кінця не вияснено.

Мета дослідження - оцінити зміни ліпідного просрілю у щурів із змодельованим метаболічним синдромом.

МЕТОДИ ДОСЛІДЖЕННЯ. Дослідження проведено на 40 білих щурах-самцях лінії Вістар масою 200-250 г (вік - 9-10 тижнів), яких утримували в стандартних умовах віварію (температура повітря - (22 \pm 2$){ }^{\circ} \mathrm{C}$, вологість - 30-60 \%, світлий/темний цикл - 12/12 год). Щурів-самців контрольної групи $(\mathrm{n}=8)$ годували звичайною контрольною дієтою. Щурів-самців основної групи ( $\mathrm{n}=32)$ годували дієтою з високим вмістом жиру (понад 60 \% енергії від жирів) упродовж 16 тижнів [9], таким чином моделюючи в них розвиток МС [10].
При проведенні експерименту дотримувалися вимог Європейської конвенції про захист хребетних тварин, що використовуються для дослідних та інших наукових цілей (Страсбург, 1986) та Директиви Європейського Союзу 2010/10/63 EU щодо експериментів на тваринах. Комісія з біоетики Тернопільського національного медичного університету імені І. Я. Горбачевського МОЗ України (протокол № 12 від 4 листопада 2020 р.) не виявила порушень морально-етичних норм під час виконання цього дослідження.

Тварин виводили з експерименту шляхом декапітації. Ліпідний профріль (загальний холестерол (ЗХС), ЛПНЩ, ЛПВЩ, ТГ) у сироватці крові щурів оцінювали за допомогою біохімічного аналізатора "HTI BioChem SA" (США) та стандартних тест-наборів ("High Technology Inc", США, “Філісіт-Діагностика”, Україна). Крім цього, розраховували коесріцієнт атерогенності (КА): (ЗХС - ЛПВЩ) / ЛПНЩ, рівень якого свідчить про ризик розвитку та прогресування атеросклерозу [11].

Статистичну обробку отриманих результатів проводили з використанням програми STATISTICA, версія 2010. Для порівняння статистичних відмінностей між групами використовували U-критерій Манна - Уїтні.

РЕЗУЛЬТАТИ Й ОБГОВОРЕННЯ. БУЛО ВСТАновлено, що на тлі перебігу МС у щурів основної групи, порівняно 3 контрольною, розвивались явища гіперхолестеринемії, які характеризувалися підвищенням у крові тварин рівнів ЗХС, ТГ, ЛПНЩ 3 одночасним зниженням вмісту ЛПВЩ. Рівні основних ліпідних показників крові на тлі MC наведено на рисунку.

Так, рівень ЗХС у тварин із змодельованим МС був на 18,38 \% вищим порівняно з контрольною групою $(p<0,05)$. Вміст ТГ у щурів основної

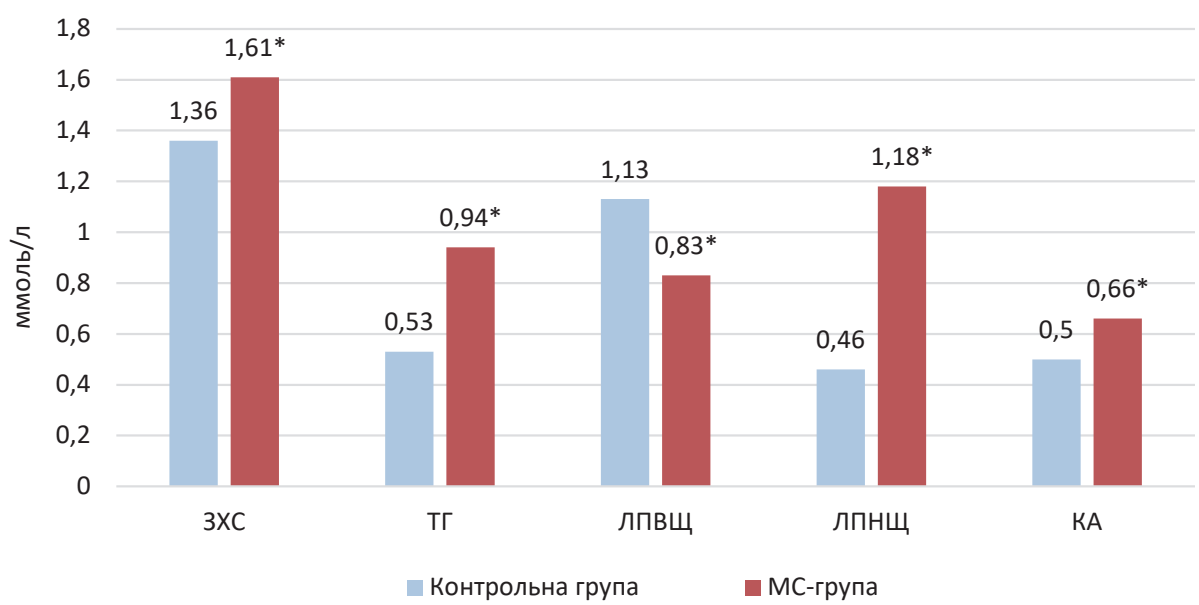

Рис. Основні показники вмісту ліпідів у крові щурів на тлі експериментального метаболічного синдрому. Примітка. * - достовірність різниці з контрольною групою. 
групи був на 77,35 \% статистично значимо більшим від такого показника в інтактних тварин. щодо ЛПНЩ, то їх рівень у щурів із змодельованим МС також був статистично значимо вищим порівняно з контрольною групою - на 156,52 \%. Враховуючи достовірні відмінності між основною та контрольною групами, можна припустити наявність у тварин, в яких у ході експерименту розвинувся МС, атерогенної дисліпідемії. Це можна розглядати як фрактор ризику розвитку серцево-судинних ускладнень при наявності МС.

щодо антиатерогенної фракції ліпідів ЛПВЩ, то їх рівень у щурів із змодельованим МС був статистично значимо нижчим на $36,14 \%$ порівняно з контрольною групою. Значення КА у тварин основної групи було на 32,00 \% вищим від такого значення в інтактних щурів $(p<0,05)$. Отримані дані свідчать про те, що на тлі висококалорійної дієти цей коефіцієнт збільшувався за рахунок статистично значимого зростання у сироватці крові рівня ЛПНЩ та зниження вмісту
ЛПВЩ ( $p<0,05)$. Тому вони можуть вказувати на прояви інсулінорезистентності у тварин основної групи. Також підвищення КА може свідчити про наявність артеріальної гіпертензії, гіперінсулінемії та гіпертригліцеридемії. Кожен із цих фракторів є маркером МС і водночас незалежним фрактором ризику розвитку атеросклерозу та серцево-судинних захворювань.

ВИСНОВОК. У тварин із метаболічним синдромом зміни ліпідного обміну характеризувалися гіпер- та дисліпідемією (за статистично значимо вищими рівнями загального холестеролу, триацилгліцеролів, ліпопротеїнів низької щільності й коефіцієнта атерогенності на тлі зниження вмісту ліпопротеїнів високої щільності) порівняно з контрольною групою. Отже, наявність метаболічного синдрому свідчить про прогресування процесів атеросклерозу та підвищений ризик розвитку серцево-судинних захворювань.

\section{СПИСОК ЛІТЕРАТУРИ}

1. Metabolic syndrome, dyslipidemia and regulation of lipoprotein Metabolism / J. Iqbal, A. A. Qarni, A. Hawwari [et al.] // Current Diabetes Reviews. - 2018. - 14 (5). P. 427-433.

2. Optimization of the complex therapy of chronic pancreatitis with metabolic syndrome / L. S. Babinets, N. A. Melnyk, N. O. Shevchenko [et al.] // Wiadomosci Lekarskie. - 2018. - No. 71 (2). - P. 337-340.

3. Grundy S. M. Metabolic syndrome update / S. M. Grundy // Trends in Cardiovascular Medicine. 26 (4). - P. 364-373.

4. Dabke K. The gut microbiome and metabolic syndrome / K. Dabke, G. Hendrick, S. Devkota // Journal of Clinical Investigation. - 129 (10). - P. 4050-4057.

5. Mumusoglu S. Metabolic syndrome during menopause / S. Mumusoglu, B. O. Yildiz // Current Vascular Pharmacology. - 2019. - 17 (6). - P. 595-603.

6. Kallikrein-kinin system disbalance in chronic pancreatis in combination with metabolic syndrome / L. S. Babinets, N. A. Melnyk, N. O. Shevchenko [et al.] // Wiadomosci Lekarskie. - 2019. - No. 72 (11, cz 1). P. 2113-2126.

7. Weihe P. Metabolic syndrome in children and adolescents: Diagnostic criteria, therapeutic options and perspectives / P. Weihe, S. Weihrauch-Blüher // Current Obesity Reports. - 2019. - 8 (4). - P. 472-479.

8. Tan K. C. Management of dyslipidemia in the metabolic syndrome / K. C. Tan // Cardiovascular and Hematological Disorders - Drug Targets. - 2007. - 7 (2). P. 99-108.

9. Моделювання метаболічного синдрому різного генезу в експериментальних тварин : метод. рек. I Державна установа "Інститут проблем ендокринної патології ім. В. Я. Данилевського Національної академії медичних наук України". - Харків, 2019. С. $10-12$.

10. Diagnosis and management of the metabolic syndrome. An American Heart Association. National Heart, Lung, and Blood Institute Scientific Statement: Executive Summary / S. M. Grundy, J. I. Cleeman, S. R. Daniels [et al.] // Circulation. - 112. - P. e285-e290.

11. Особливості змін ліпідограми крові щурів за метаболічного синдрому та фрармакотерапії екстрактом плодів горобини звичайної та ресвератролом / Н. О. Мархонь, В. І. Жилюк, А. Е. Лєвих, В. И. Мамчур // Фармакологія та лікар. токсикологія. - 2017. № 2 (53). - C. 69-75. 


\section{REFERENCES}

1. Iqbal, J., Qarni, A.A., Hawwari, A., Alghanem, A.F., \& Ahmed, G. (2018). Metabolic syndrome, dyslipidemia and regulation of lipoprotein metabolism. Current Diabetes Reviews, 14 (5), 427-433.

2. Babinets, L.S., Melnyk, N.A., \& Shevchenko, N.O. (2018). Optimization of the complex therapy of chronic pancreatitis with metabolic syndrome. Wiadomosci Lekarskie, 71 (2), 337-340.

3. Grundy, S.M. (2016). Metabolic syndrome update. Trends in Cardiovascular Medicine, 26 (4), 364-373.

4. Dabke, K., Hendrick, G., \& Devkota, S. (2019). The gut microbiome and metabolic syndrome. Journal of Clinical Investigation, 129 (10), 4050-4057.

5. Mumusoglu, S., \& Yildiz, B.O. (2019). Metabolic syndrome during menopause. Current Vascular Pharmacology, 17 (6), 595-603.

6. Babinets, L.S., Melnyk, N.A., Shevchenko, N.O., Migenko, B.O., Zaets, T.A. (2019). Kallikrein-kinin system disbalance in chronic pancreatis in combination with metabolic syndrome. Wiadomosci Lekarskie, 72 (11 cz 1), 2113-2126.
7. Weihe, P., \& Weihrauch-Blüher S. (2019). Metabolic syndrome in children and adolescents: Diagnostic criteria, therapeutic options and perspectives. Current Obesity Reports, 8 (4), 472-479.

8. Tan, K.C. (2007). Management of dyslipidemia in the metabolic syndrome. Cardiovascular and Hematological Disorders - Drug Targets, 7 (2), 99-108.

9. (2019). Modeling of metabolic syndrome of different genesis in experimental animals (guidelines). State Institution "Institute of Endocrine Pathology. V.Ya. Danilevsky of the National Academy of Medical Sciences of Ukraine". Kharkiv [in Ukrainian].

10. Grundy, S.M., Cleeman, J.I., \& Daniels, S.R. (2005). Diagnosis and management of the metabolic syndrome. An American Heart Association. National Heart, Lung, and Blood Institute Scientific Statement: Executive Summary. Circulation, 112, e285-e290.

11. Markhon, N.O., Zhilyuk, V.I., Levykh, A.E., \& Mamchur, V.Y. (2017). Features of changes in the lipid profile of the blood of rats in metabolic syndrome and pharmacotherapy with mountain ash fruit extract and resveratrol. Pharmacology and Drug Toxicology, 2 (53), 69-75 [in Ukrainian].

I. Ya. Dziubanovskyi, A. M. Prodan, S. R. Pidruchna, N. A. Melnyk, T. Ya. Yaroshenko I. HORBACHEVSKY TERNOPIL NATIONAL MEDICAL UNIVERSITY

\section{CHANGES IN THE LIPID PROFILE OF ANIMALS WITH SIMULATED METABOLIC SYNDROME}

\section{Summary}

Introduction. The formation of atherogenic changes in the lipid profile of metabolic syndrome (MS) is due to the action of many risk factors. Atherogenic dyslipoproteinemia is not only a risk factor for the development and progression of atherosclerosis, but also one of the main components of MS.

The aim of the study - to evaluate changes in the lipid profile of rats with simulated MS.

Research Methods. The study was performed on 40 white male Wistar rats weighing 200-250 g. The control group included 8 animals. Male rats of the main group $(n=32)$ were fed a diet high in fat (over $60 \%$ energy from fat) for 16 weeks, thus modeling their development of MS. Animals were removed from the experiment by decapitation. The lipid profile in the serum of rats was evaluated using a biochemical analyzer HTI BioChem SA (USA) and standard test kits.

Results and Discussion. It was found that against the background of MS, the rats of the main group compared with controls developed hypercholesterolemia, which was characterized by an increase in animal blood levels of total cholesterol (TC) by $18.38 \%$, triglycerides (TG) by $77.35 \%$, low-density lipoprotein (LDL) by $156.52 \%$ with a simultaneous decrease in high-density lipoproteins (HDL) by $36.14 \%$.

Conclusions. In animals with MS, changes in lipid metabolism were characterized by hyper-and dyslipidemia (statistically significantly higher levels of TC, TG, LDL on the background of the destruction of HDL) compared with controls.

KEY WORDS: lipoproteins; triglycerides; lipid profile; metabolic syndrome.

Адреса для листування: С. Р. Підручна, Тернопільський національний медичний університет імені І. Я. Горбачевського МОз України, майдан Волі, 1, Тернопіль, 46001, Україна, e-mail: pidruchna@tdmu.edu.ua. 